\title{
MINIGRID ELECTRICITY SERVICE BASED ON LOCAL AGRICULTURAL RESIDUES: FEASIBILITY STUDY IN RURAL AFRICA
}

\author{
$\underline{\text { Pol Arranz-Piera }^{1,2}}$, Francis Kemausuor ${ }^{3,4}$, Lawrence Darkwah ${ }^{4,5}$, Ishmael Edjekumhene ${ }^{6}$, Joan \\ Cortés ${ }^{1}$, Enrique Velo ${ }^{1}$ \\ ${ }^{1}$ Department of Heat Engines, Universitat Politècnica de Catalunya, Barcelona, Spain \\ ${ }^{2}$ Trama Tecnoambiental (TTA), Barcelona, Spain \\ ${ }^{3}$ Department of Agricultural and Biosystems Engineering, College of Engineering, KNUST, Kumasi, Ghana \\ ${ }^{4}$ The Brew-Hammond Energy Center, College of Engineering, KNUST, Kumasi, Ghana \\ ${ }^{5}$ Department of Chemical Engineering, College of Engineering, KNUST, Kumasi, Ghana \\ ${ }^{6}$ Kumasi Institute of Technology \& Environment (KITE), P. O. Box AT 720, Achimota, Accra, Ghana
}

Corresponding author: pol.arranz.piera@upc.edu

\begin{abstract}
The Sustainable Development Goals (SDGs) are emphatic on the role of energy for development. Targets include ensuring universal access to affordable, reliable and modern energy services to the about 1.3 billion people without electricity access, and to increase substantially the share of renewable energy in the global energy mix. For remote rural communities in developing countries where grid extension is often expensive, decentralised biomass mini-grids can be a reliable electricity supply source, as it provides 'base load' power and avoids the use of 'excessive' storage batteries. This paper presents a feasibility study for five rural communities in Ghana. Results show that the projected electricity demand of the communities compares favourably with the potential energy generation from available agricultural residues, and that there is a case for considering various levels of co-funding from private investors.
\end{abstract}

Keywords

Rural electrification, Biomass gasification, Agricultural residues, Energy planning, Feasibility studies, Ghana. 


\section{Introduction}

Even though the Millennium Development Goals (MDGs) did not have a specific target for energy, it was globally agreed that energy was the one thing that underpins the success of all the goals. The newly formulated Sustainable Development Goals (SDGs) was therefore emphatic on the role of energy for development. Goal 7 of the SDGs aim to 'ensure access to affordable, reliable, sustainable and modern energy for all' (United Nations, 2016). The targets of Goal 7 are to achieve, inter alia, the following by 2030 :

- ensure universal access to affordable, reliable and modern energy services;

- increase substantially the share of renewable energy in the global energy mix;

- double the global rate of improvement in energy efficiency; and

- expand infrastructure and upgrade technology for supplying modern and sustainable energy services for all in developing countries, especially least developed countries, small island developing States, and land-locked developing countries, in accordance with their respective programmes of support.

Per the first three targets, Goal 7 is directly supporting the implementation of the "Sustainable Energy for All (SEforAll)' agenda launched by the United Nations Secretary General, which has been embraced by many developing countries (Mensah et al., 2014).

The broad aim is to reach the 1.3 billion people that still live without electricity, most of them in rural areas of Asia and sub-Saharan Africa. For many countries in these regions, the main barrier to $100 \%$ electricity access is supply to rural areas which are not connected to the electricity grid (Alfaro et al., 2016; Azimoh et al., 2016; Eder et al., 2015). Sub-Saharan Africa has more people living without access to electricity than any other world region - more than 620 million people, and nearly half of the global total. It is also the only region in the world where the number of people living without electricity is increasing, as rapid population growth is outpacing the many positive efforts to provide access. In thirty-seven (37) sub-Saharan countries, the number of people without electricity has increased since 2000 while the regional total rose by around 100 million people (OECD/IEA, 2014). Only a few countries, including Ghana and South Africa, have managed to increase access to electricity to a higher percentage. But even for the few countries with higher access, achieving high rural electrification rates remains a challenge, with a present national average rural access to electricity rate of about $50 \%$ (Kemausuor and Ackom, 2016).

Ghana is an example of a sub-Saharan African country that has invested in rural electrification systems. This is part of a National Electrification Scheme that has been under implementation since 1990, to ensure universal access to electricity in the country by 2020. Ghana has also subscribed to the SEforALL agenda and was the first country to prepare an SEforALL Action Plan (Mensah et al., 2014). Ghana's SE4ALL action plan (now transformed into an action agenda), aims to continue the drive for rural electrification and promote productive uses of electricity (Government of Ghana, 2012). Currently, about $15 \%$ of the population (an estimated 4 million people), living in sparsely populated rural communities, remain unconnected to electricity (Kemausuor and Ackom, 2016). A significant portion of this population live in lakeside and island communities on the Volta Lake, which means that grid extension to these communities may require expensive underwater cables. Generally, grid based electrification to these communities is highly uneconomical (Nerini, 2016). Meanwhile, many of such rural 
communities produce agricultural residues and other biomass types that could be converted using biomass based power plants to meet their electricity demands (Arranz-Piera et al., 2017). This system of power generation, apart from providing the rural communities with self-sufficient energy (ESMAP, 2016), can also generate employment and other development opportunities for the rural inhabitants, through the productive use programme being targeted by the national SEforALL programme. This paper presents a feasibility study for decentralised mini-grid electricity services using agricultural residue in rural communities in Africa. The aim of the study was to investigate how the effective utilization of local agricultural waste can provide electricity using a biomass gasification system.

\section{Material and Methods}

\subsection{Study Communities}

The study was conducted in Ghana, West Africa. Five rural communities were selected for the study. The five communities were selected based on previous experience with Multi-Functional Platforms (MFPs) implemented in Ghana from 2006-2008 (Kemausuor et al., 2011). Three of the communities, Seneso, Bompa and Boniafo are located in the Atebubu-Amantin district of the Brong Ahafo Region, whereas Nakpaye and Jaman Nkwanta are respectively located in the East Gonja and Kpandai districts of the Northern Region of Ghana (see map in Figure 1).

\section{FIGURE 1}

\subsection{Study Approach}

\section{First Phase}

The first Phase of the study consisted of a general analysis of the project, and data collection. It involved a desk review of available information for the study communities and preliminary visit to familiarise with the communities and their leadership structure. Thereafter, data was collected by conducting a series of surveys in the communities. Unlike existing studies on rural electrification in Ghana and West Africa, this study relied more on primary data collected from the field, as opposed to using secondary data. Primary data collection occurred through field visits using a 2-phase approach as summarised in Figure 2. Details of sampling for the survey is shown in Table 1.

\section{TABLE 1}

\section{FIGURE 2}

\section{Second Phase}

In the second Phase of the study, detailed calculations were made on different aspects of the proposed community mini-grids, using the data collected in the first phase. The communities were then ranked based on the results of this assessment, using a scale developed to reflect the 
relative feasibility of the project in these localities. The ranking methodology could aid policy makers and planners when faced with a decision to prioritise communities for mini-grid electrification. Factors considered in the analysis were socio-economic factors, technical and technological factors, and financial factors.

\subsection{Data Collection and Analysis}

\subsubsection{Socio-economic Assessment}

Phase 1 of the socio-economic assessment consisted of a community appraisal. Each of the 5 communities were visited and assessed in terms of the demographics: population, housing characteristics and economic activities. Primary data was collected for all these indicators. All the communities are predominantly farming communities. Other economic activities include, trading, charcoal production, cattle rearing (for communities in the Northern Region) and fish mongering (for communities in the Brong Ahafo region).

In Phase 2, analysis of electricity demand was undertaken, based on the activities of the community. The estimation of current as well as future demand was based on four (4) main load categories in a minigrid (IFC-ERC, 2015 and GDEE, 2015): residential, institutional, commercial and industrial. The residential consumption includes private households (HHs) where energy is consumed primarily for lighting and as input for the provision of other services (including room conditioning, refrigeration, entertainment/communication, etc.). Residential consumptions have been segmented further into four (4) consumption classes defined primarily by the consumption profile of residential customers in a similar but electrified community (meter readings facilitated by the local utility, Northern Electricity Distribution Company Limited (NEDCO)). Institutional consumption represents the consumptions of public institutions in the community. Public lighting, public water pumping, energy use in religious buildings, schools and health centres have been considered in this category. Consumption levels for this category are derived from the field surveys and the demographic and social characteristics of each community. Commercial consumption represents the potential electricity to be consumed by commercial bodies identified during the field surveys and these include: dressmaking, minishops, drinking bars, hairdressing salons, etc. Their consumption is related to each community's characteristics. Industrial consumption represents the potential electricity to be consumed by small industrial concerns identified in the field surveys such as the MFP operation. The consumption depends on the operational cycle of the concerned industry.

The estimated electricity demand for each category is then aggregated to give the projected total energy consumption for the first year of the planning period. In determining how the yearly consumption and peak demand will evolve year by year over the projected planning period, three scenarios were considered: Baseline Scenario, Alternative Scenario 1 and Alternative Scenario 2.

- The Baseline Scenario estimates the potential electricity consumption in the five (5) communities, assuming these communities had access to electricity at the time of the study. The baseline electricity consumption was based on energy consumption patterns found within projects implemented by the Ghana Ministry of Energy (TTA, 2017), with similar socio-economic characteristics.

- Alternative Scenario 1 considers the evolution of yearly consumption and peak demand over the period 2017-2027, driven by population growth. In this scenario, yearly consumption 
(and peak demand) is projected to increase as population of the communities increases. The increase in consumption will be accounted for by increases in household demand, school demand (as result of increased demand for lighting and in most cases demand for computing services) and the demand for more public lighting.

- Alternative Scenario 2 projects the evolution of yearly consumption and peak demand over the planning period (2017-2027) due to population growth and a socio-economic growth to be experienced in the communities, largely attributed to the provision of electricity. The improvement in the socio-economic status of community members and businesses is expected to give rise to increases in household demand (particularly in the demand categories that include the utilisation of a fridge or a freezer), in commercial demand (as a result of new businesses springing up and existing ones acquiring more equipment, etc.) and in institutional demand (as a result of the use of more and better equipment/appliances in these institutions and the establishment of health centres, which were not considered in the baseline scenario) (ESMAP, 2016).

\subsubsection{Technical and Technological Assessment}

Previous studies on rural electrification have flagged the reduction of logistic problems and the convenient economics of considering distributed power generation facilities as close as possible to locations where biomass is abundant (Asadullah, 2014). In Phase 1 of our technical analysis, the availability of local biomass residues was investigated. Based on data collected in farmer fields, the overall quantities of crop residue that could be available were estimated, with consideration for alternative uses as spelt out in Blanco-Canqui and Lal (2009). Reference values on residue to product ratios (RPR) were obtained from previous studies in Ghana (Kemausuor et al., 2016; Ayamga et al., 2015) to estimate crop residue availability. Lower Heating Values (LHV) for energy potential estimation were obtained from Arranz-Piera, et al. (2017).

In Phase 2 of the technological analysis, the present and future electricity demands are computed, and then compared to the electricity supply available from biomass, in order to ascertain the possibility of satisfying energy demand solely from agricultural waste.

The next step assessed the technical feasibility of providing energy using only biomass feedstock. Previous reviews have identified gasification as the most promising small scale (below 100kW) solid biomass to electricity conversion technology (Mohammed et al., 2013, Gonzalez et al., 2015). To assess electricity production potential, a reference efficiency conversion factor of $18 \%$ was applied, using a downdraft fixed bed gasifier coupled to an Otto engine gas generator set (Mazzola, 2016; Dasappa, 2011). Recent studies on small scale gasification experiences in rural Africa Owen and Ripken, 2017) have pointed out the importance of proper O\&M for a reliable operation of this technology.

\subsubsection{Financial Assessment}

The financial assessment is an essential part of the final decision-making process. The financial viability analysis of the project was conducted to determine how the project will fare under various scenarios. The Net Present Value (NPV) and the Internal Rate of Return (IRR) were the indicators used to measure the viability of the project. Sensitivity analyses were also conducted 
by varying the funding sources mix (Grant vs Private equity), the potential cost of biomass (no cost, 5 or 10 US\$ per tonne) and electricity selling tariffs against the NPV. Table 2 shows the assumptions made in conducting the financial analysis (TTA, 2017. IRENA, 2012. Owen and Ripken, 2017).

TABLE 2

\section{Results and Discussion}

\subsection{Biomass Resource Availability and Electricity Generation}

The annual quantity of agricultural residues generated in each community is presented in Table 3. The assessment established that between 211 and 586 tonnes of agricultural residues are generated in the communities annually, which can be converted to electricity using a biomass gasification technology (Mazzola, 2016; Dasappa, 2011). Table 4 shows the potential electricity that can be obtained from the crop residues available at each target community. Maize residues dominate electricity generation potential, ranging from 35 to $74 \%$ of the total electricity potential.

\section{TABLE 3}

TABLE 4

\subsection{Electricity Demand Projections}

Electricity demand projections were made using data obtained from the community survey, as well as demand segmentation observed from pilot mini-grids in the country; Table 5 shows the demand segmentation patterns being observed at the Ghana Ministry of Energy piloted minigrids (TTA, 2017. Peters and Imboden, 2017), and the corresponding categorisation under the energy availability quality factors developed by the U.S. National Renewable Energy Laboratory (NREL, 2016). Table 5 indicates that $95 \%$ of potential customers (mainly households) would be consuming up to $100 \mathrm{kWh} / \mathrm{month}$ (VL, L and $\mathrm{M}$ categories) in the Baseline Scenario and Scenario 1. In scenario 2, households will evolve from their respective categories to the nearest demand categories due to increase in energy consumption (with the highest increase given in the $M$ category, that enables the use of a fridge or a freezer). As a result, the potential customers consuming up to $100 \mathrm{kWh} / \mathrm{month}$ are expected to decline to $80 \%$ while the number of households consuming above $100 \mathrm{kWh}$ will increase to $20 \%$.

The daily load profiles have been defined by a percentage distribution of energy consumed in hourly periods for the different demand categories (TTA, 2017. Peters and Imboden, 2017). Detailed demand data for the Seneso community is shown in Table 6. Summary for all the five communities is shown in Table 7. Load profiles have been defined to ensure correct sizing of the micro power plant and mini grid in each community. Figures 3 and 4 show load profiles for Seneso Community for the Baseline in 2017 and Scenario 2 in 2027 respectively. Typical of the national situation in Ghana, peak demand occurs between 6:00pm and 11:00pm, the period 
between close of daily activities and bedtime (Energy Commission, 2016). In both instances, residential demand dominates, also typical of the national picture (Energy Commission, 2016).

Figure 5 shows electricity demand values compared with the potential electricity generation from the biomass resources available within the communities (Table 4). For all three scenarios, electricity potential from the available biomass is higher than the demand computed. In the Boniafo, the potential electricity from biomass is about 4 times the electricity demand from scenario 2.

\section{TABLE 5}

TABLE 6

TABLE 7

FIGURE 3

FIGURE 4

FIGURE 5

\subsection{Technical and Operational Feasibility Benchmarking}

Combining the aspects investigated in the biomass resource assessment and the socio-economic analysis, the communities were ranked in terms of ease of implementation of biomass technology for electricity generation. An evaluation methodology was developed to assign scores to the communities based on the criteria developed in Table 8. Each criterion can be scored on a scale of 1 (low) to 4 (very high). The criteria for evaluation are heavily dependent on the community typology, thus inter-household distances, radius of the community, and distance from the existing grid. The Geographic Information System (GIS) layout for one of the communities is shown in Figure 6.

\section{FIGURE 6}

Weights were given to each criterion depending on its position on the priority scale (Table 8). An overall score above 3.5 was given a high feasibility rating, and a score below 1.9 given a low score. In between the two were medium (between 2 and 2.9), and high (between 3 and 3.4). As shown in Table 9, only one community had a very high score, with two others scoring a high, and the remaining two scoring a medium. None of the communities had a low score.

\section{TABLE 8}

TABLE 9 
Finally, the engineering outline of the mini-grids was carried out, considering a hybrid biomass syngas genset supply architecture (with batteries), as described in Figure 7. Tables 10 and 11 show the general operating conditions and technical specifications respectively, of the mini-grid design for the community of Seneso, which had the very high score. The proposed distribution mini-grid for the Seneso community is also shown in Figure 8.

\section{FIGURE 7}

\section{FIGURE 8}

\subsection{Financial Assessment Results}

The financial results for Seneso Community, which has the highest feasibility score, are shown in Figures 9, 10 and 11. In Seneso, the field work revealed that on average, households spend close to GHS 50.00 (approx. US\$ 12.5) worth of electrical energy services in a month (on lighting with candles, kerosene lamps or torches, and mobile phone charging.

Figure 8 shows that if the initial investment costs are subsidized entirely, the minimum tariff that would balance the replacement and M\&O\&M costs would be $8.8 \mathrm{US} \$$ cents $/ \mathrm{kWh}$, equivalent to an average payment per user of about 4.3 US\$ per month.

Biomass is assumed to be available at no cost in Figure 9. If biomass was priced at 5 US\$ per tonne, then the minimum tariff would be 9.5 US\$ cents $/ \mathrm{kWh}$ (average payment of 4.7 US $\$$ /month). If it was priced at 10 US\$ per tonne, then the minimum tariff would be 10 US\$ cents/kWh (average payment of 5 US\$/month).

If the current average household electricity expenditure were charged to customers, profitability of the business would be enhanced, as shown in Figure 10, with all other conditions set to those in Figure 9.

The case of private funding has also been considered, under the assumption that a $15 \%$ minimum return on equity would be expected by investors over a 20-year project lifetime period. Figure 11 shows the minimum tariff that would need to be charged to users to reach IRR profitability levels of $15 \%$ and $25 \%$ for several shares of private co-funding. Figure 11 also shows that by applying a customer tariff equivalent to the current expenditure on electricity equivalent uses in Seneso (12.5 US\$/month), a subsidy of about $35 \%$ on initial investment would enable a profitability of $15 \%$. In order to reach a profitability of $25 \%$, an investment subsidy of $60 \%$ would be required. It can also be concluded from Figure 11 that by applying national uniform tariffs (End User Tariff (EUT)) ${ }^{1}$, which as of January 2017 were set at about 17.7 US\$ cents/kWh (including service charge), $65 \%$ of the investment costs would need to be subsidized to enable a $15 \%$ profitability, with the remaining $35 \%$ coming from private co-funding.

\section{FIGURE 9}

FIGURE 10

\section{FIGURE 11}

\footnotetext{
${ }^{1}$ Available from the Ghana Public Utilities Regulatory Commission, http://www.purc.com.gh/purc/node/177
} 


\section{Conclusions}

Planning rural electrification projects in developing countries can be a challenging activity for project planners. In this paper, we have presented a feasibility study for the development of standalone minigrid electricity service in rural communities in Africa using their own agricultural residues, in a case study comprising five Ghanaian farming communities which have benefited from previous MFPs and are therefore well positioned for such interventions. The study takes into consideration four key components that have been assessed: socio-economic, technical, organizational and financial. The technical analysis shows that electricity demand of the study communities compares favourably with the potential electricity generation from biomass resources available within the communities; in three electricity demand scenarios, the potential electricity generation from the locally available biomass is higher than the demand for electricity. As with most biomass electricity analysis, it is not profitable from the perspective of an entrepreneur with $100 \%$ private funding; however, by applying a customer tariff equal to the current expenditure on electricity equivalent uses in the communities, a subsidy of about $35 \%$ on initial investment would enable a private investor profitability of $15 \%$, whereas a $60 \%$ subsidy could enable a profitability of $25 \%$. Applying the national electricity uniform tariff would require a $65 \%$ of the investment subsidies to enable a $15 \%$ profitability, with the remaining $35 \%$ coming from private co-funding. The case studies were conducted in previous MFP communities because of their experience in dealing with biomass systems and conversion technologies. But we do not envisage much difficulty in transferring these case studies to communities that have not been involved in MFPs. However, more sensitisation and further training would be required in such communities. Another aspect of further research can be the consideration of solar photovoltaic (PV) generation to complement the biomass gasification plant.

\section{Acknowledgements}

The authors wish to acknowledge financial support from the ECOWAS Centre for Renewable Energy and Energy Efficiency (ECREEE), and the UPC Centre for Cooperation for Development (CCD).

\section{References}

[1] United Nations (2016). Sustainable development goals: 17 goals to transform the world. Available from http://www.un.org/sustainabledevelopment/sustainable-developmentgoals/. Accessed 11 September 2017

[2] Mensah, G. S., Kemausuor, F., and Brew-Hammond, A. (2014). Energy Access Indicators and Trends in Ghana. Renewable and Sustainable Energy Reviews 30: 317-323

[3] Alfaro, J.F., Miller, S., Johnson, J.X., Riolo, R.R. (2016). Improving rural electricity system planning: An agent-based model for stakeholder engagement and decision making. Energy Policy, ISSN 0301-4215.

[4] Azimoh, C.L., Klintenberg, P., Wallin, F., Karlsson, B., Mbohwa, C. (2016). Electricity for development: Mini-grid solution for rural electrification in South Africa. Energy Conversion and Management 110: 268-277. 
[5] Eder, J.M., Mutsaerts, C.F., Sriwannawit, P. (2015). Mini-grids and renewable energy in rural Africa: How diffusion theory explains adoption of electricity in Uganda. Energy Research \& Social Science 5: 45-54.

[6] OECD/IEA (2014). Africa Energy Outlook: a focus on energy prospects in sub-Saharan Africa. Available from https://www.iea.org/publications/.../publication/WEO2014_AfricaEnergyOutlook.pdf. Accessed 14 November 2016

[7] GLSS (2014) Ghana Living Standards Survey Round 6. Community Facility Report. http://www.statsghana.gov.gh/glss6.html. Accessed 20 May 2017.

[8] Government of Ghana (2012). Ghana sustainable energy for all action plan. Available from energycom.gov.gh/files/SE4ALL-GHANA\%20ACTION\%20PLAN.pdf . Accessed $25^{\text {th }}$ September 2017.

[9] Kemausuor, F., Ackom, E. (2016). Towards Universal Electrification in Ghana. WIREs Energy Environ 2016. doi: 10.1002/wene.225

[10] Arranz-Piera, P., Kemausuor, F., Addo, A., Velo, E. (2017). Electricity generation prospects from clustered smallholder and irrigated rice farms in Ghana, Energy, Volume 121: $246-255$.

[11] ESMAP (2016). Ghana: Mini-Grids for Last-Mile Electrification. Available from news.org/fileadmin/DATEIEN/Dateien/New/ESMAP_Ghana_Mini_grids_for_last_Mile_E lectrification_Optimized.pdf. Accessed 1 November 2016

[12] Nerini, F.F, Broad, O., Mentis, D., Welsch, M., Bazilian, M., Howells, M. (2016). A cost comparison of technology approaches for improving access to electricity services. Energy 95: 255-265

[13] Kemausuor, F., Obeng, G. Y., Brew-Hammond, A. and Duker, A. (2011). A Review of Trends, Policies and Plans for Increasing Energy Access in Ghana. Renewable and Sustainable Energy Reviews 15: 5143-5154

[14] IFC-ERC, eds. (2015). Kenya Market Assessment for Off-Grid Electrification. Carbon Africa Limited, Trama TecnoAmbiental (TTA),Research Solutions Africa Limited,Energy Research Centre of the Netherlands. October 2015.

[15] GDEE (eds.) 2015, Case studies for developing globally responsible engineers, Global Dimension in Engineering Education, Barcelona. Available from: http://gdee.eu/index.php/resources.html

[16] NREL (2016) Quality Assurance Framework for Mini-Grids. National Renewable Energy Laboratory U.S. Department of Energy. Available from www.nrel.gov/docs/fy17osti/67374.pdf

[17] TTA (2017). Minigrid project reference by Trama Tecnoambiental (TTA), Barcelona. Accessed 1st October 2017. http://www.tta.com.es/en/electric-microgrids

[18] Peters, C., Imboden, C. Ghana turns to mini-grids for electrification of isolated rural areas. PV-Tech Power. Solar Powering Africa: Special Report: 18-19. April 2017. Accessed 22nd August 2017. https://www.pv-tech.org/pv-tech-power/solar-poweringafrica-special-report. 
[19] Asadullah, M. Barriers of commercial power generation using biomass gasification gas: A review, In Renewable and Sustainable Energy Reviews, Volume 29, 2014, Pages 201215.

[20] Blanco-Canqui, H., Lal, R. (2009). Crop Residue Removal Impacts on Soil Productivity and Environmental Quality. Critical Reviews in Plant Sciences 28: 139-163.

[21] Kemausuor, F., Bolwig, S., Miller, S. (2016). Modelling the socio-economic impacts of modern bioenergy in rural communities in Ghana. Sustainable Technologies and Assessments 14: 9-20

[22] Ayamga, E. A., Kemausuor, F., Addo, A. (2015). Technical analysis of crop residue biomass energy in an agricultural region of Ghana. Resources, Recycling and Conservation 96: $51-60$.

[23] Mohammed, Y.S., Mokhtar, A.S. , Bashir, N. , Saidur, R. (2015). An overview of agricultural biomass for decentralized rural energy in Ghana, Renewable and Sustainable Energy Reviews 20: 15-25.

[24] González, A., Riba, J., Puig, R., Navarro, P. (2015). Review of micro- and small-scale technologies to produce electricity and heat from Mediterranean forests' wood chips, Renewable and Sustainable Energy Reviews 43: 143-155.

[25] Mazzola, S., Astolfi, M., Macchi, E. (2016). The potential role of solid biomass for rural electrification: A techno economic analysis for a hybrid microgrid in India. Applied Energy 169: 370-383.

[26] Dasappa, S. (2011). Potential of biomass energy for electricity generation in sub-Saharan Africa. Energy for Sustainable Development, 15 (3): 203-213

[27] IRENA (2012). Renewable energy technologies: Cost Analysis series: Biomass for Power Generation. vol. 1. 2012.

[28] Owen, M. and Ripken, R. (2017). Technology Country Case Study Report. For the Department for International Development, United Kingdom. Bioenergy for Sustainable Energy Access in Africa project. Published by LTS International Limited, the University of Edinburgh and E4tech (UK) Limited. Unpublished

[29] Kemausuor, F. (2015). Assessment of technical potential and selected sustainability impacts of second generation bioenergy in Ghana. PhD Thesis. Kwame Nkrumah University of Science and Technology, Ghana

[30] Energy Commission (2016). 2016 Energy (Supply and Demand) Outlook for Ghana. Available from http://energycom.gov.gh/files/Energy\%20Outlook\%20 for\%20Ghana\%20\%202015.pdf. Accessed September 20, 2016). 

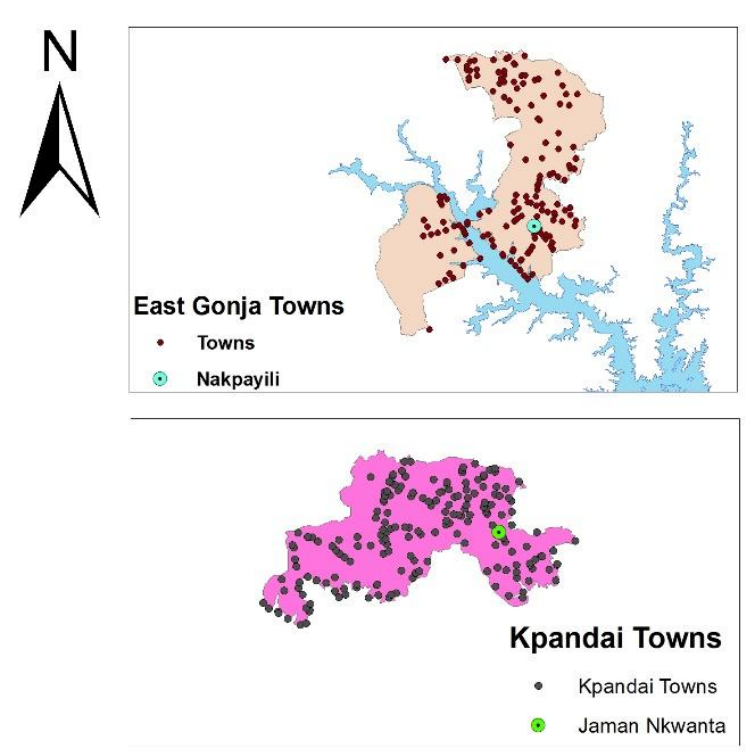

Atebubu Amantin Towns

- Atebubu-Amantin Towns

- Bompa

- Boniafo

- Seneso

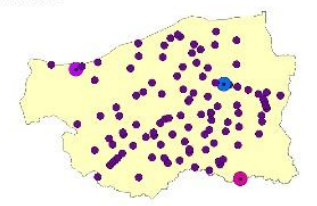

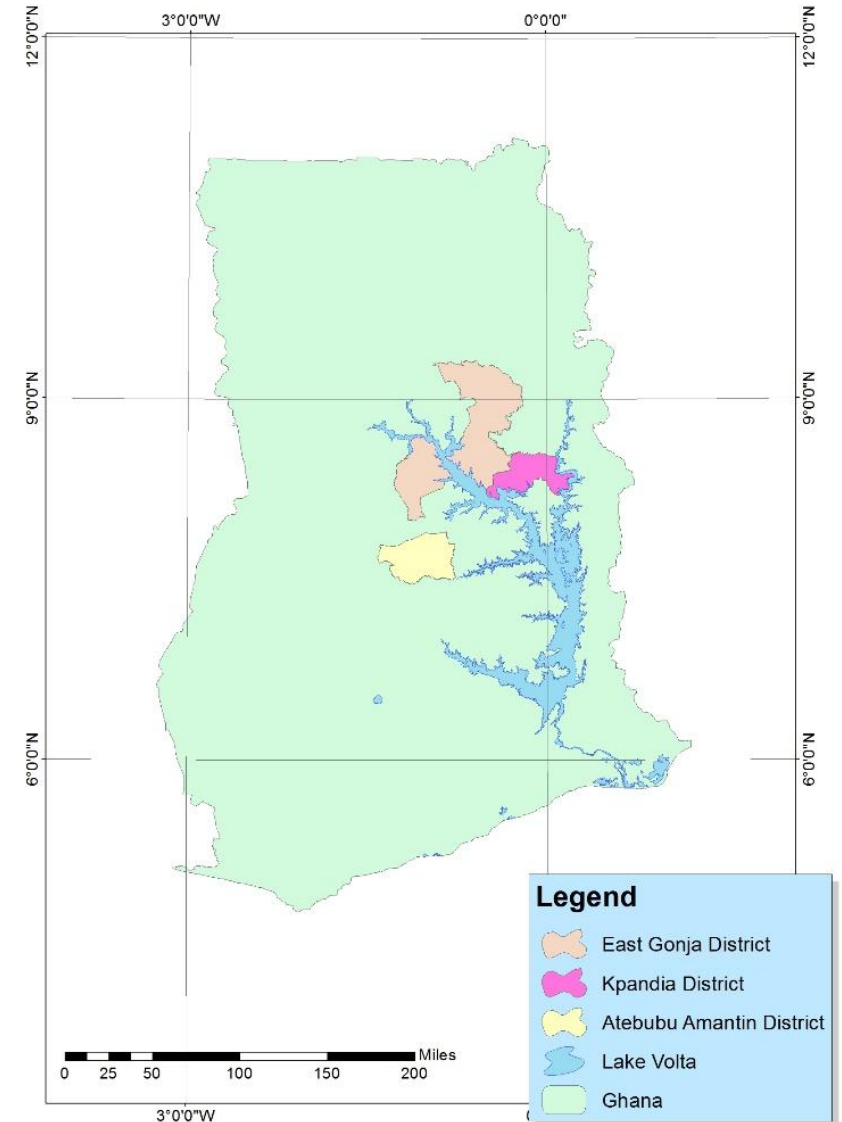

Figure 1: The five Ghanaian rural communities that participated in this project

\section{Phase1}

\section{A. Desk review and inception:}

A.1 Feasibility analysis methodology adaptation (components, quantified criteria, protocols)

A. 2 Desk review of available information

\section{B. Field work:}

B.1 Preparation of field work: materials, logistics

B.2 Field visits to 5 MFP communities

\section{Phase 2}

C. Detailed Feasibility: characterisation and community analysis

(Analysis of Socio-economic, Technical, Institutional and Financial components)

D. Ranking of communities potentials

Figure 2 : Methodology used in implementing study 


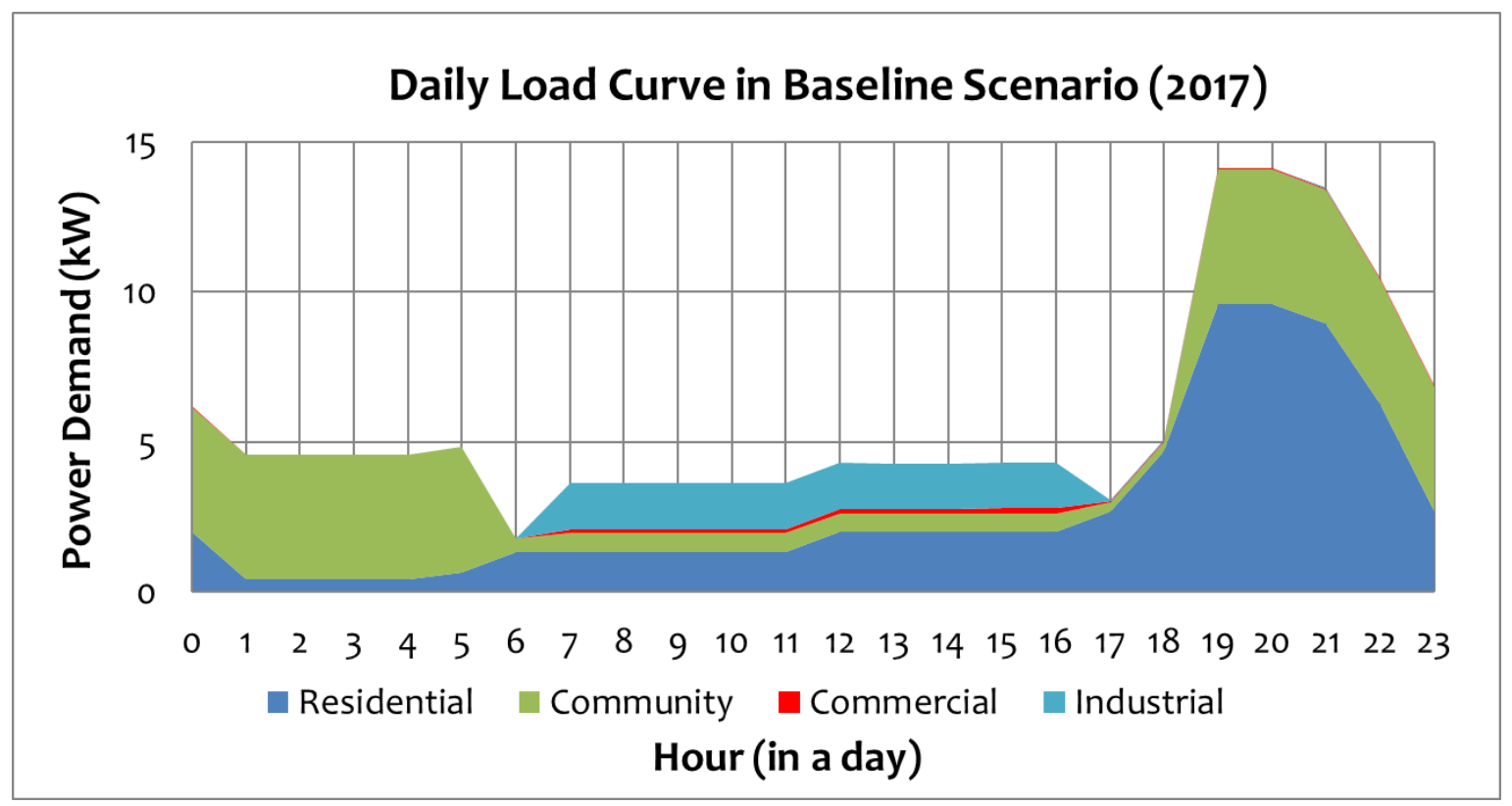

Figure 3: Load profile for the Seneso Community in the Baseline Scenario

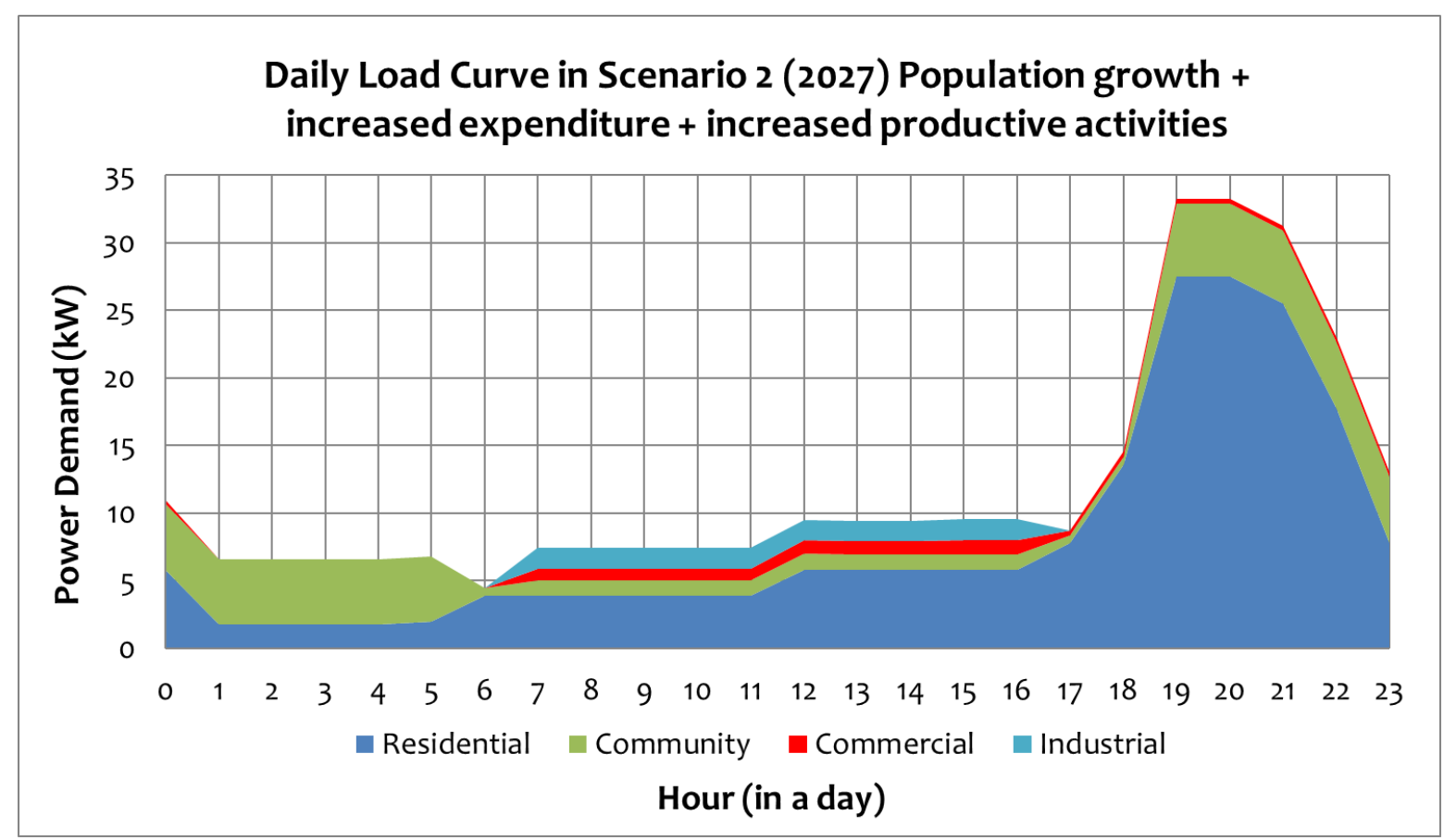

Figure 4: Load profile for the Seneso Community in Scenario 2 


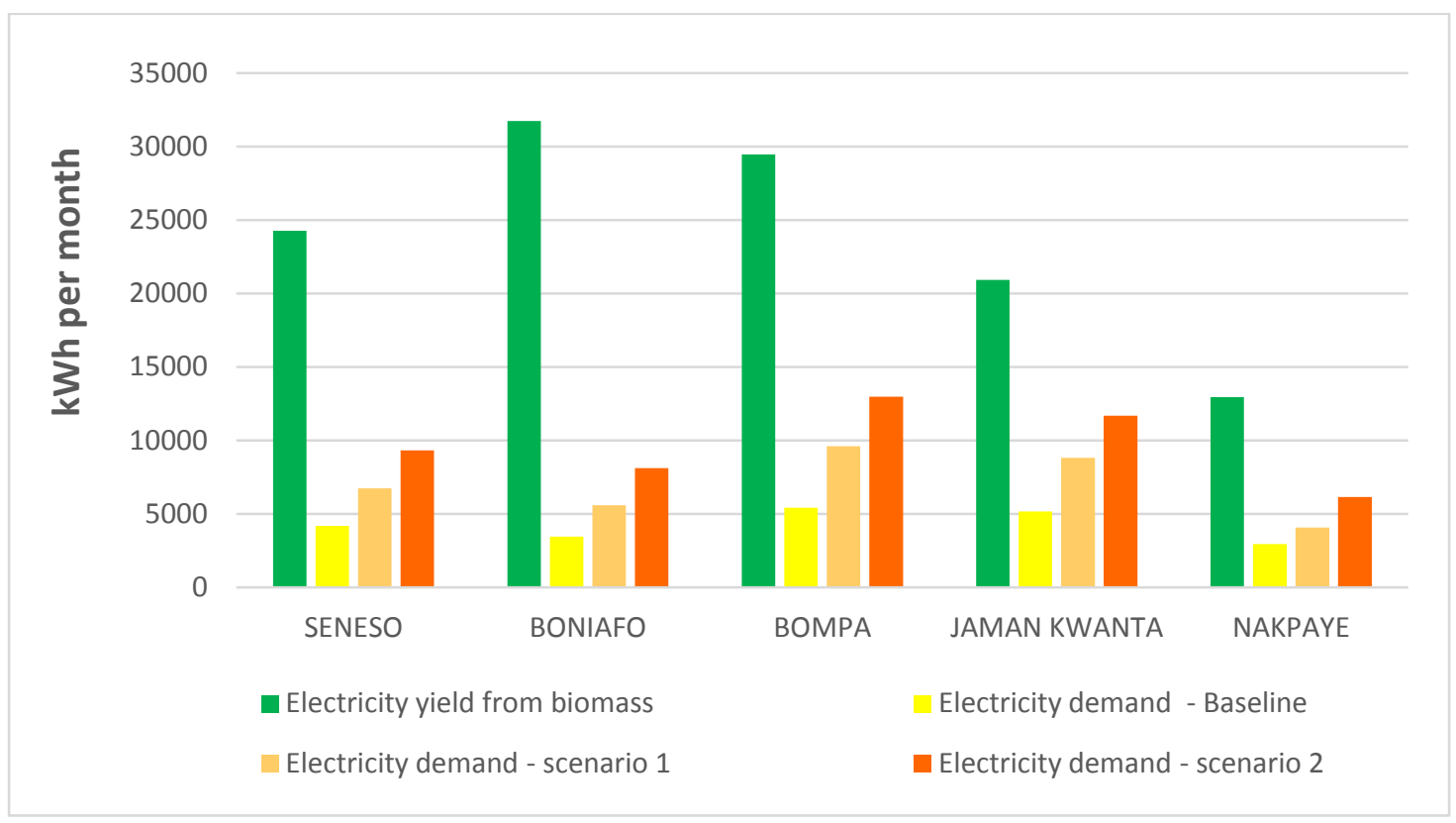

Figure 5: Summary of the electricity generation potential from crop residues compared to the electricity demand in each target community

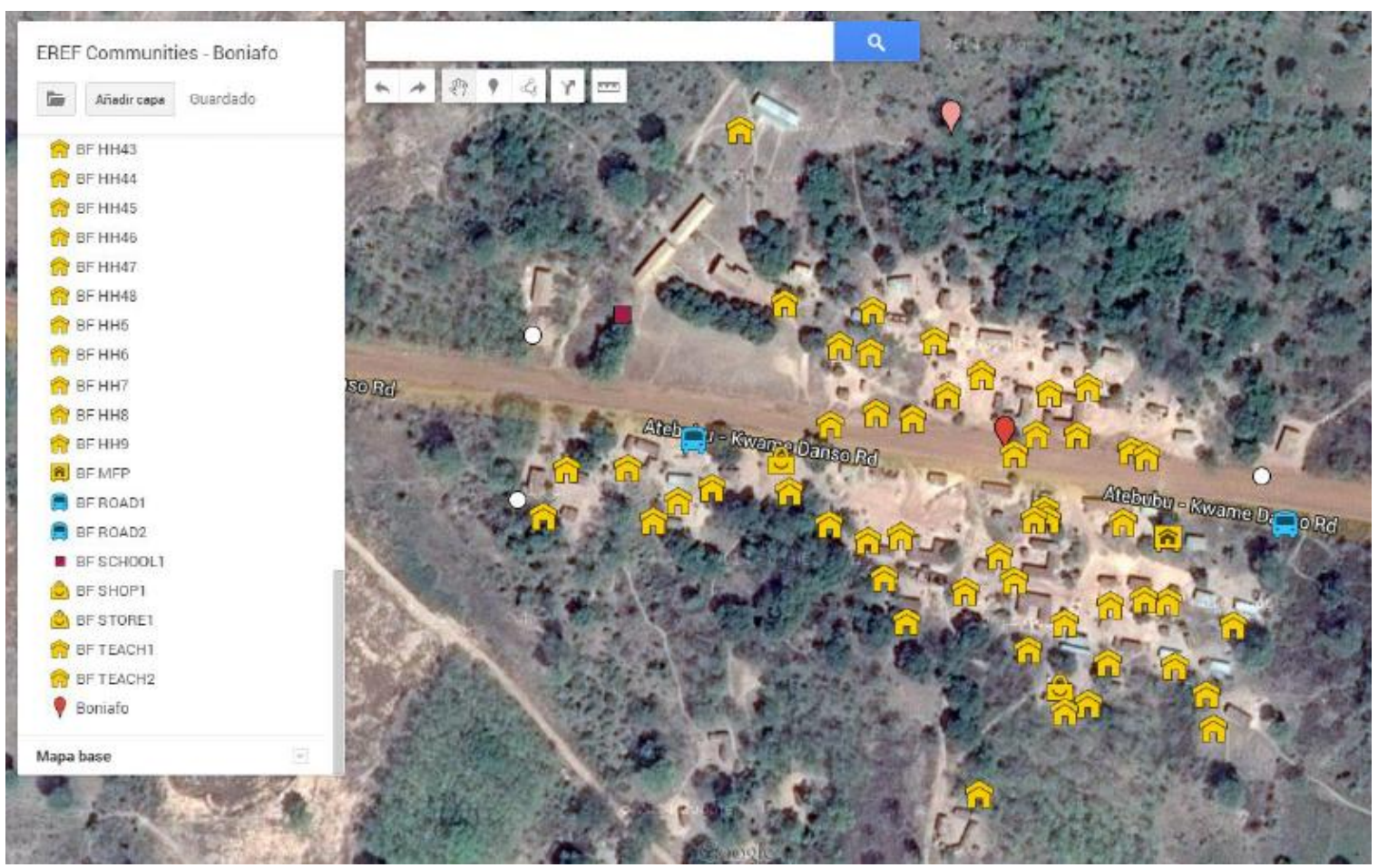

Figure 6: Boniafo community layout, showing a clustered topology (schema obtained plotting own GPS data on Google Maps engine). 


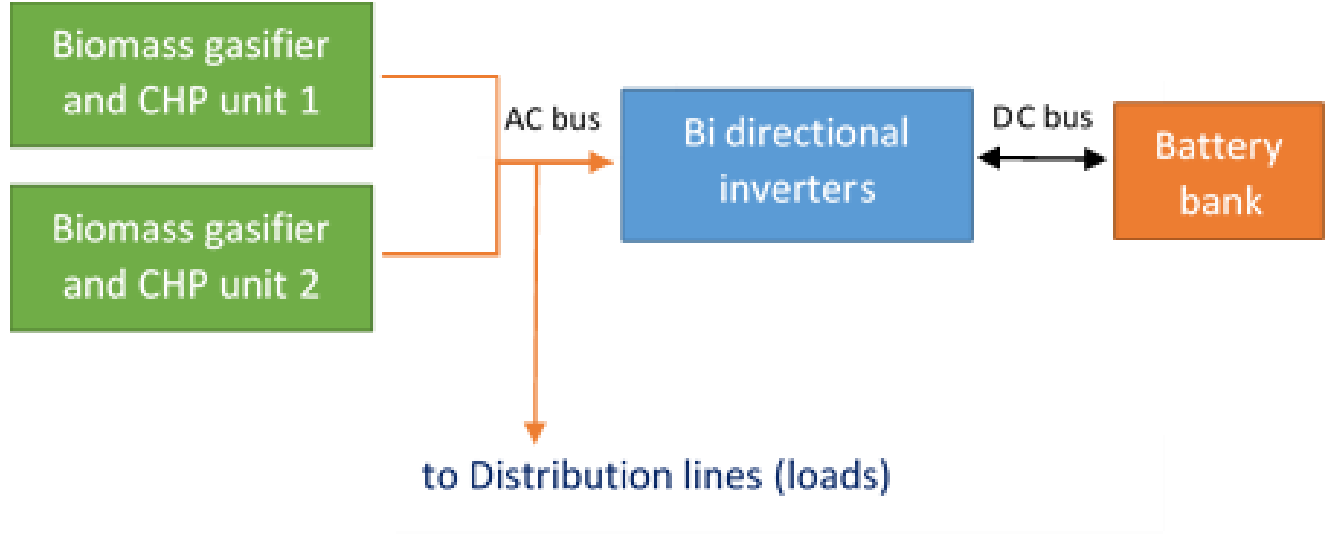

Figure 7. Block diagram of biomass hybrid generation architecture

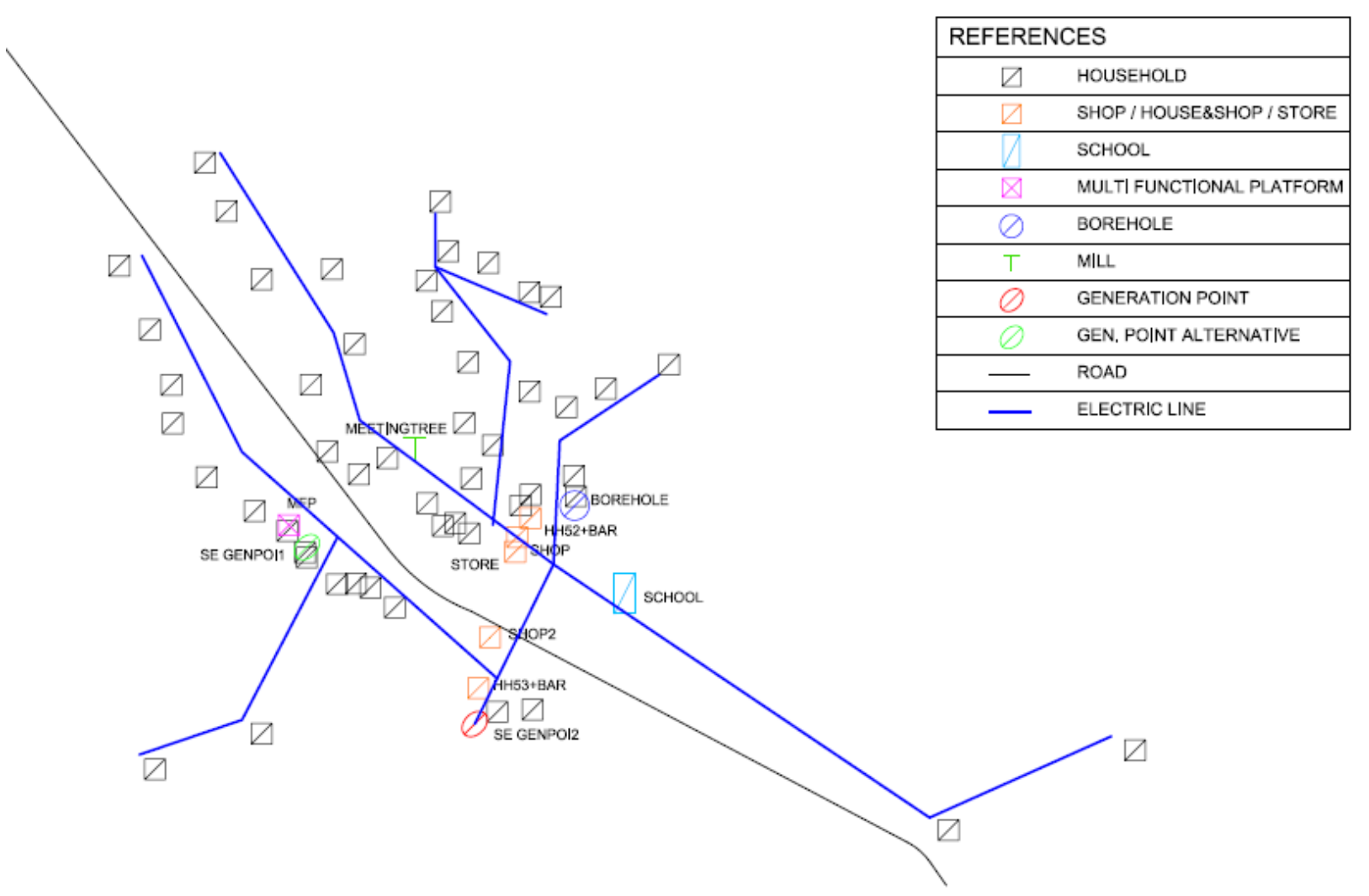

Figure 8. Distribution mini-grid outline for Seneso 


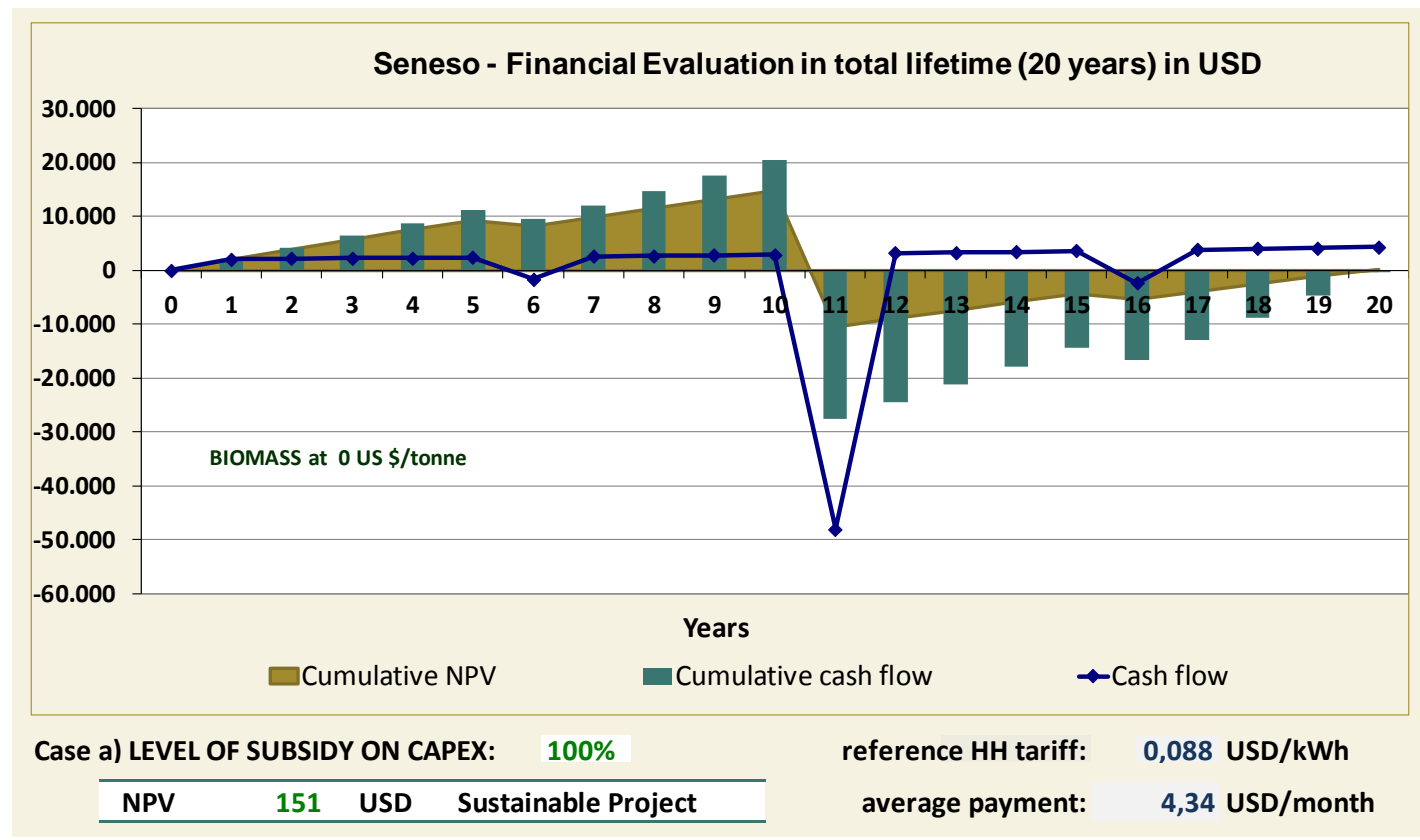

Figure 9: Financial analysis of a 24-7 electricity service in the community of Seneso under a $100 \%$ subsidy funding scheme, with biomass supplied at no cost, using minimum tariff for financial viability

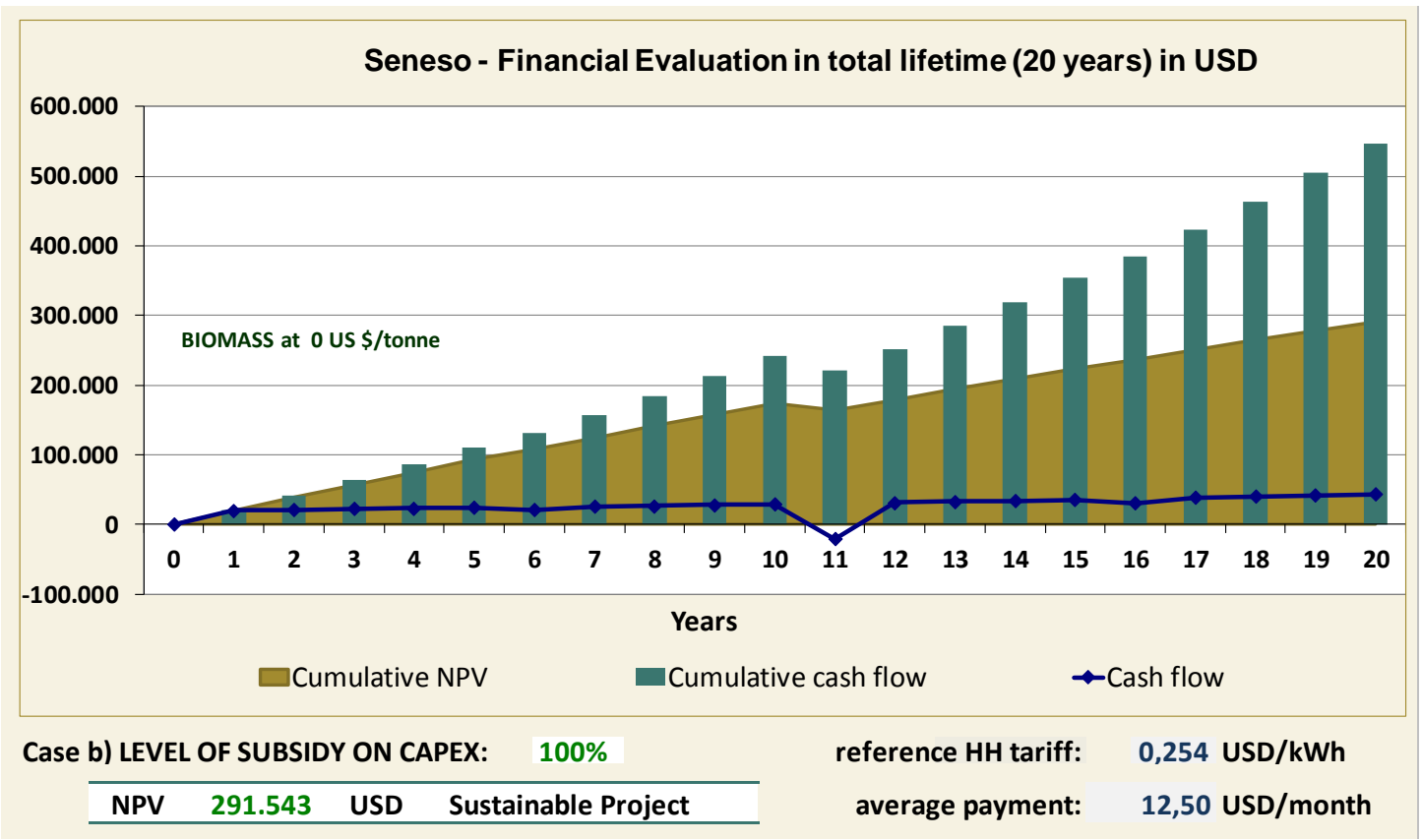

Figure 10: Financial analysis of a 24-7 electricity service in the community of Seneso under a $100 \%$ subsidy funding scheme, with biomass supplied at no cost, using tariff equivalent to current average expenditure 


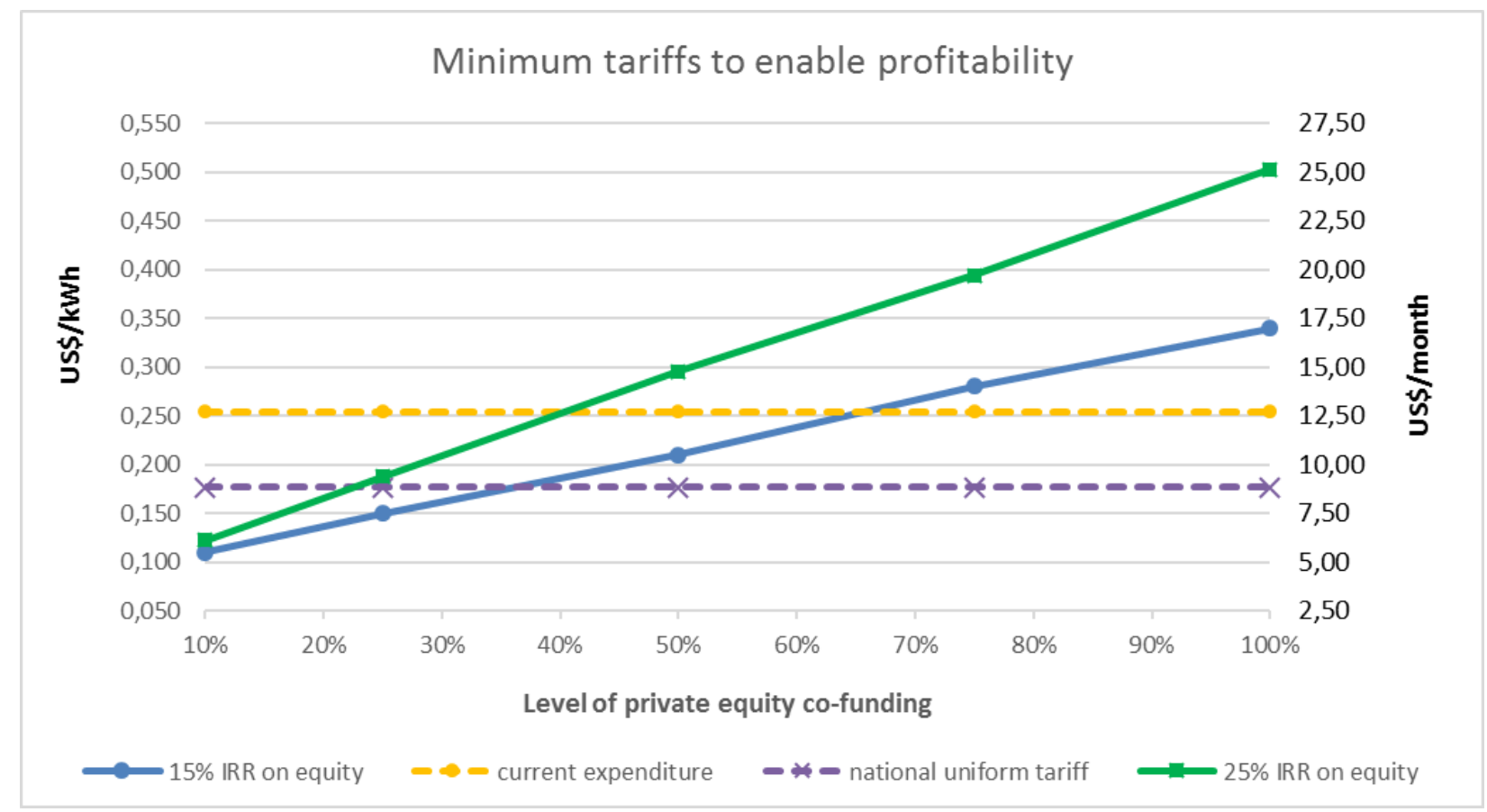

Figure 11: Financial analysis of a 24-7 electricity service in the community of Seneso under several levels of private co-funding 
Table 1: Sampling for survey in five communities

\begin{tabular}{|l|c|c|c|c|}
\hline Community & Population & $\begin{array}{c}\text { No. of } \\
\text { households }\end{array}$ & $\begin{array}{c}\text { Households } \\
\text { interviewed }\end{array}$ & $\begin{array}{c}\text { Farmers } \\
\text { interviewed }\end{array}$ \\
\hline Seneso & 528 & 52 & 22 & 12 \\
\hline Bompa & 614 & 63 & 25 & 17 \\
\hline Boniafo & 635 & 68 & 25 & 19 \\
\hline Nakpaye & 894 & 55 & 23 & 19 \\
\hline Jaman Nkwanta & 586 & 71 & 25 & 22 \\
\hline Total & 3,257 & 309 & 120 & 89 \\
\hline
\end{tabular}

Table 2: Assumptions used in financial analysis

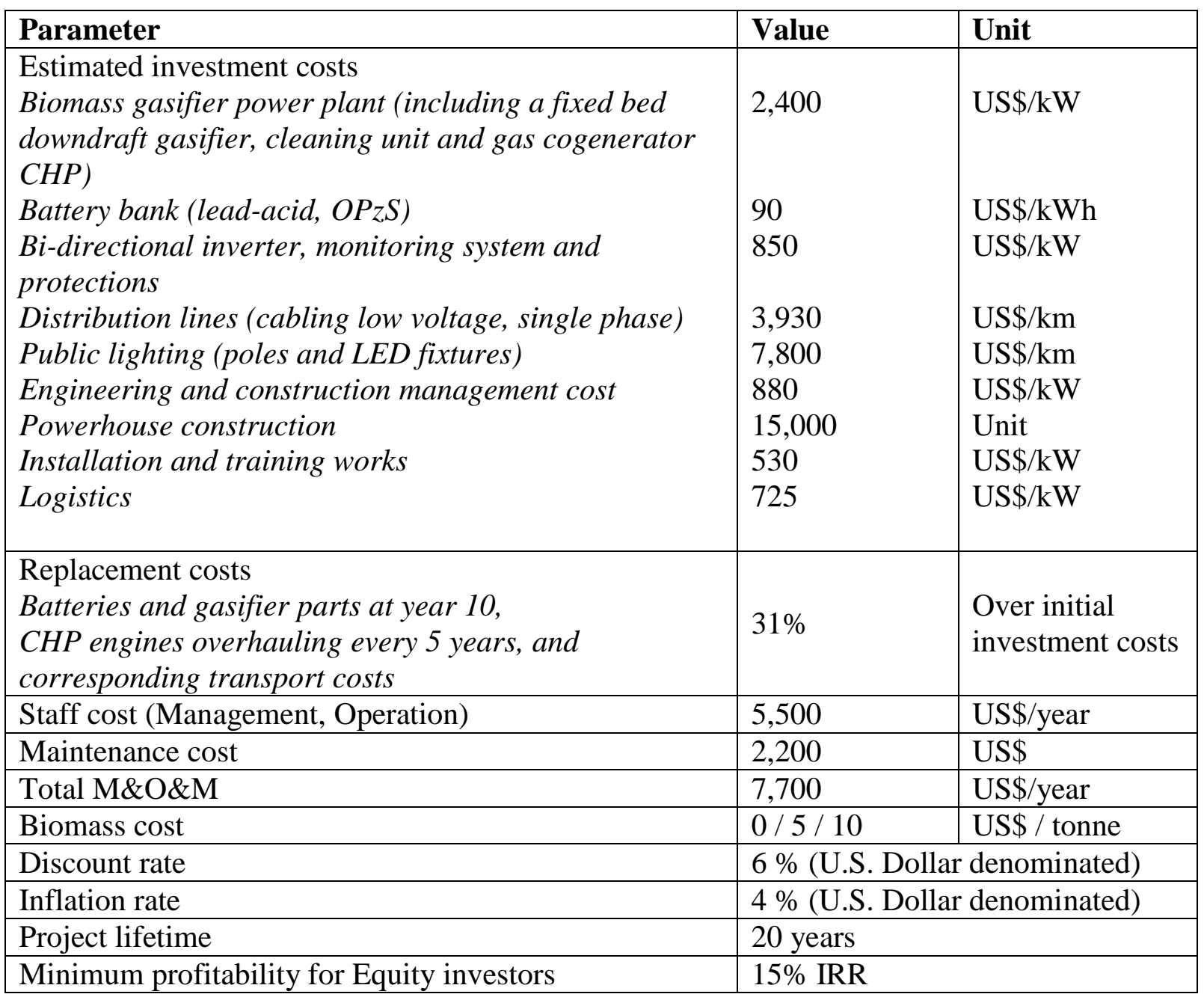


Table 3: Annual crop residue production in each target community

\begin{tabular}{|l|c|c|c|c|c|c|}
\cline { 2 - 6 } \multicolumn{1}{c|}{} & \multicolumn{4}{c|}{ Estimated Crop Residue (kg) per year } & \multirow{2}{*}{$\begin{array}{c}\text { *Assumed moisture } \\
\text { content (\%, wet basis) }\end{array}$} \\
\hline Type of Residue & Seneso & Boniafo & Bompa & Jaman & Nakpaye & 15.02 \\
\hline Maize stalk & 171,477 & 261,942 & 92,895 & 67,910 & 40,339 & 8.01 \\
\hline Maize cob & 57,159 & 87,314 & 30,965 & 22,637 & 13,446 & 11.23 \\
\hline Maize husks & 68,591 & 104,777 & 37,158 & 27,164 & 16,136 & 16.45 \\
\hline Beans Straw & 49,958 & 2,046 & 24,631 & 29,184 & 25,648 & 16.45 \\
\hline Beans shells & 13,322 & 546 & 6,568 & 7,782 & 6,840 & 18.86 \\
\hline Groundnut straws & 44,234 & 39,466 & 29,406 & 18,761 & 12,629 & 13.82 \\
\hline Groundnut shells & 9,786 & 8,731 & 6,506 & 4,151 & 2,794 & 15.50 \\
\hline Rice straw & 3,205 & 10,050 & 118,839 & 5,752 & 19,173 & 13.01 \\
\hline Rice husk & 534 & 1,675 & 19,807 & 959 & 3,195 & 20.00 \\
\hline Cassava stalks & 4,692 & 28,523 & 6,306 & 19,851 & 20,179 & 63.57 \\
\hline Millet straw & - & - & 788 & 6,040 & 6,723 & 61.80 \\
\hline Guinea Corn straw & - & - & - & - & 2,096 & 15.00 \\
\hline Yam Straw & 8,935 & 40,711 & 103,765 & 222,727 & 42,147 & \\
\hline TOTAL (kg) & $\mathbf{4 3 1 , 8 9 1}$ & $\mathbf{5 8 5 , 7 8 1}$ & $\mathbf{4 7 7 , 6 3 3}$ & $\mathbf{4 3 2 , 9 1 8}$ & $\mathbf{2 1 1 , 3 4 6}$ & \\
\hline
\end{tabular}

*Values obtained in experiments conducted in Ghana by Kemausuor (2015)

Table 4: Potential electricity generation from crop residue in each target community

\begin{tabular}{|l|c|c|}
\hline \multirow{2}{*}{ Community } & \multicolumn{2}{|c|}{ Monthly Electricity yields (kWh/month)* } \\
\cline { 2 - 3 } & All crops & Maize only \\
\hline Seneso & 24,264 & 15,486 \\
\hline Boniafo & 31,743 & 23,656 \\
\hline Bompa & 29,457 & 10,487 \\
\hline Jaman Nkwanta & 20,928 & 7,666 \\
\hline Nakpaye & 12,954 & 4,554 \\
\hline
\end{tabular}

* efficiency conversion factor of $18 \%$ 
Table 5: Reference mini-grid customer demand segmentation for baseline and scenario 1

\begin{tabular}{|c|c|c|c|}
\hline Demand profile* & $\begin{array}{c}\text { Correspondence with } \\
\text { Energy Service } \\
\text { Levels by NREL }\end{array}$ & $\begin{array}{c}\text { Baseline \& scenario 1 } \\
\text { (\% of households })\end{array}$ & $\begin{array}{c}\text { Scenario 2 } \\
\text { (\% of households) }\end{array}$ \\
\hline VL & Level 1 & 17 & 10 \\
\hline L & Level 2 & 63 & 30 \\
\hline M & Level 3 & 15 & 40 \\
\hline H & Level 4 & 5 & 20 \\
\hline
\end{tabular}

*Very Low (VL): HHs consuming up to $10 \mathrm{kWh} / \mathrm{month}$. Households in this category are expected to use electricity for only basic lighting and very small communications appliances like radios or mobile phone chargers.

Low (L): HHs consuming between 10 and $35 \mathrm{kWh} /$ month. Households in this category are expected to use fan and/or $\mathrm{TV}$ in addition to the VL load.

Medium (M): HHs consuming between 35 and $100 \mathrm{kWh} /$ month. Households in this category are expected to add small refrigerators in addition to L load.

High $(\mathrm{H})$ : Households consuming more than $100 \mathrm{kWh} / \mathrm{month}$.

Table 6: Electricity demand projections (case of Seneso community)

\begin{tabular}{|c|c|c|c|c|}
\hline \multicolumn{2}{|c|}{$\begin{array}{l}\text { Electricity demand in SENESO } \\
\text { community }\end{array}$} & $\begin{array}{l}\text { Baseline } \\
\text { Scenario }\end{array}$ & $\begin{array}{l}\text { Scenario } 1 \\
\text { (population }\end{array}$ & $\begin{array}{c}\text { Scenario } 2 \\
(\text { Scenario } 1+\end{array}$ \\
\hline \multirow[t]{5}{*}{ Residential } & HHs VL $(<20 \mathrm{kWh})$ & 95 & 200 & 106 \\
\hline & HHs L $(<50 \mathrm{kWh})$ & 990 & 2080 & 870 \\
\hline & HHs M $(<100 \mathrm{kWh})$ & 670 & 1410 & 2830 \\
\hline & HHs H (>100 kWh) & 280 & 590 & 2120 \\
\hline & Total (kWh/month) & 2035 & 4280 & 5926 \\
\hline \multicolumn{2}{|c|}{ Institutional (kWh/month) } & 1640 & 1950 & 2070 \\
\hline \multicolumn{2}{|c|}{ Commercial (kWh/month) } & 50 & 50 & 370 \\
\hline \multicolumn{2}{|c|}{ Industrial (kWh/month) } & 470 & 470 & 960 \\
\hline \multicolumn{2}{|c|}{ Total $(\mathrm{kWh} / \mathrm{month})$} & 4195 & 6750 & 9326 \\
\hline \multicolumn{2}{|c|}{ Total (kWh/day) } & 138 & 222 & 307 \\
\hline \multicolumn{2}{|c|}{ Peak power demand $(\mathrm{kW})$} & 14.1 & 25.5 & 33.5 \\
\hline
\end{tabular}

Table 7: Demand forecast for the five communities

\begin{tabular}{|l|c|c|c|c|c|c|}
\hline \multirow{2}{*}{ Community } & \multicolumn{3}{|c|}{ Electricity (kWh/month) } & \multicolumn{3}{c|}{ Power peak (kW) } \\
\cline { 2 - 7 } & Baseline & Scenario 1 & Scenario 2 & Baseline & Scenario 1 & Scenario 2 \\
\hline Seneso & 4195 & 6750 & 9326 & 14.1 & 25.5 & 33.5 \\
\hline Boniafo & 3443 & 5595 & 8126 & 12.7 & 22.5 & 29.7 \\
\hline Bompa & 5422 & 9602 & 12972 & 21.2 & 40.4 & 53.4 \\
\hline Jaman Nkwanta & 5174 & 8822 & 11683 & 18.9 & 35.8 & 47.3 \\
\hline Nakpaye & 2938 & 4076 & 6147 & 8.4 & 13.5 & 18.1 \\
\hline
\end{tabular}


Table 8: Criteria for the feasibility weighted scoring

\begin{tabular}{|c|c|c|}
\hline \multicolumn{2}{|c|}{ Scoring values } & \multirow{2}{*}{$\begin{array}{l}\text { Criterion: Community topology. Weight: } \mathbf{2 0 \%} \\
\text { dispersed HHs: interdistance }>100 \mathrm{~m} \text {, overall radius }>2 \mathrm{~km} \text {; distance to grid }<5 \mathrm{~km}\end{array}$} \\
\hline 1 & low & \\
\hline 2 & medium & clustered HHs: interdistance $<100 \mathrm{~m}$, overall radius $<2 \mathrm{~km}$; distance to grid $<5 \mathrm{~km}$ \\
\hline 3 & high & clustered HHs: interdistance $<50 \mathrm{~m}$, overall radius $<1 \mathrm{~km}$; distance to grid $>5 \mathrm{~km}$ \\
\hline 4 & very high & clustered HHs: interdistance $<30 \mathrm{~m}$, overall radius $<500 \mathrm{~m}$; distance to grid $>5 \mathrm{~km}$ \\
\hline \multicolumn{2}{|c|}{ Scoring values } & $\begin{array}{l}\text { Criterion: Current energy use and expenditure. Weight: } 20 \% \\
\text { IUS } \$=4 \text { GHS (April 2017) }\end{array}$ \\
\hline 1 & low & Average expenditure $<10 \mathrm{GHS} /$ month. No community uses, No productive uses \\
\hline 2 & medium & Average expenditure < $30 \mathrm{GHS} / \mathrm{month}$. No community uses, No productive uses \\
\hline 3 & high & Average expenditure > $30 \mathrm{GHS} /$ month. No community uses, No productive uses \\
\hline 4 & very high & $\begin{array}{l}\text { Average expenditure }>60 \mathrm{GHS} / \text { month. Community \& Productive uses, Experience with } \\
\text { electricity }\end{array}$ \\
\hline \multicolumn{2}{|c|}{ Scoring values } & Criterion: Potential generation from biomass waste. Weight: $40 \%$ \\
\hline 1 & low & $<10 \%$ electricity demand, worst case scenario \\
\hline 2 & medium & $>30 \%$ electricity demand, worst case scenario \\
\hline 3 & high & $>70 \%$ electricity demand, worst case scenario \\
\hline 4 & very high & $>90 \%$ electricity demand, worst case scenario \\
\hline \multicolumn{2}{|c|}{ Scoring values } & Criterion: Management model prospects. Weight: $20 \%$ \\
\hline 1 & low & Community not organised: no basic O\&M nor Administration capacity \\
\hline 2 & medium & Some organisation: no basic O\&M nor Administration capacity \\
\hline 3 & high & Some organisation, basic Administration capacity or basic O\&M capacity \\
\hline 4 & very high & Community well organised, basic O\&M capacity and basic Administration capacity \\
\hline
\end{tabular}

Table 9: Technical and Operational feasibility results

\begin{tabular}{|l|c|c|c|c|c|}
\hline & Seneso & Boniafo & Bompa & $\begin{array}{c}\text { Jaman } \\
\text { Nkwanta }\end{array}$ & Nakpaye \\
\hline Community topology & 4 & 3 & 4 & 4 & 2 \\
\hline Current energy use and expenditure & 3 & 2 & 3 & 3 & 3 \\
\hline $\begin{array}{l}\text { Potential generation from biomass } \\
\text { waste }\end{array}$ & 4 & 4 & 3 & 2 & 3 \\
\hline Management model prospects & 4 & 3 & 2 & 2 & 2 \\
\hline Overall (weighted) rating & 3.8 & 3.2 & 3.0 & 2.6 & 2.6 \\
\hline Feasibility score & very high & high & high & medium & medium \\
\hline
\end{tabular}


Table 10: General Operating conditions used to model the mini-grid case for Seneso

\begin{tabular}{|l|l|}
\hline Electricity service supply & $\begin{array}{l}307 \mathrm{kWh} \text { per day. } \\
\text { Availability: 24 hours a day, 7 days a week }\end{array}$ \\
\hline $\begin{array}{l}\text { Powerhouse gross active } \\
\text { electric power }\end{array}$ & $34 \mathrm{~kW}$ in AC (50Hz) \\
\hline Powerhouse configuration & $\begin{array}{l}\text { 2 gasifier based CHP systems, for direct electricity supply to the } \\
\text { mini-grid and battery charging }\end{array}$ \\
\hline $\begin{array}{l}\text { Electricity supply } \\
\text { configuration }\end{array}$ & $\begin{array}{l}\text { Gasifier maximum operation of 9 hours per day (reported by } \\
\text { manufacturers), at 18 \% electrical efficiency (conservative } \\
\text { estimation) } \\
\text { Gasifier 1 - operating 12am to 9pm } \\
\text { Gasifier 2 - operating 8am to 12am, and 6pm to 11pm } \\
\text { Batteries - 11pm to 8am }\end{array}$ \\
\hline $\begin{array}{l}\text { Average agrowaste } \\
\text { specific consumption }\end{array}$ & $\begin{array}{l}\text { 0.8 kWh electric / kg agrowaste } \\
\text { Considering a LHV of } 4 \mathrm{kWh} / \mathrm{kg}, \text { at } 30 \% \mathrm{MC} \text { (on dry basis) of } \\
\text { biomass received at the powerhouse }\end{array}$ \\
\hline
\end{tabular}

Table 11: Technical specifications and CAPEX of the mini-grid case for Seneso

\begin{tabular}{|c|c|c|c|c|}
\hline Component & Value & Unit & $\begin{array}{l}\text { Reference } \\
\text { manufacturer }\end{array}$ & $\begin{array}{l}\text { Reference } \\
\text { investment cost } \\
\text { (US\$) }\end{array}$ \\
\hline Biomass gasifier CHP plant & $2 \times 17$ & $\mathrm{~kW}$ & HUSK POWER & 81,600 \\
\hline Lead-acid Battery bank & 90 & $\mathrm{kWh}$ & $\begin{array}{l}\text { SUNLIGHT RES } \\
\text { OPzV }\end{array}$ & 8,000 \\
\hline Inverter & 8 & $\mathrm{kVA}$ & STUDER & 5,800 \\
\hline Monitoring system & 1 & unit & TTA & 1,000 \\
\hline $\begin{array}{l}\text { Powerhouse ( } 3 \text { rooms) with } \\
\text { fence }\end{array}$ & 30 & $\mathrm{~m}^{2}$ & Local builders & 15,000 \\
\hline Distribution lines (aerial) & 1500 & $\mathrm{~m}$ & TTA & 5,900 \\
\hline Public lighting (LED) & 60 & poles & TTA & 11,700 \\
\hline $\begin{array}{l}\text { User connection, smart meters } \\
\text { and indoor wiring }\end{array}$ & 140 & users & TTA & 22,400 \\
\hline Installation & \multicolumn{3}{|c|}{ Based on TTA references } & 13,000 \\
\hline Logistics & \multicolumn{3}{|c|}{ Based on TTA references } & 24,600 \\
\hline Project Development & \multicolumn{3}{|c|}{ Based on TTA references } & 35,000 \\
\hline \multicolumn{4}{|l|}{ Total CAPEX US\$ } & 224,000 \\
\hline
\end{tabular}

